\title{
TINJAUAN HUKUM ISLAM TERHADAP PEMBERIAN UANG ADAT (SELEMAK SEMANIS) DALAM PERKAWINAN ADAT MELAYU JAMBI
}

\author{
Siti Marlina \& Rahmi Hidayati* \\ Universitas Islam Negeri (UIN) Sulthan Thaha Saifuddin Jambi \\ Email: siti.marlina58@uinjambi.ac.id
}

\begin{abstract}
The background of the problem in this research is, in Jambi in the traditional wedding ceremony there is what is called adat money (Selemak Semanis), which is the traditional money given by men to women who will be married if the adat money is not fulfilled so it will not happen marriage. As for the purpose of this study, we want to know the position and legal consequences of giving customary money in Jambi Malay customary marriage, wanting to know the legal consequences of giving customary money in Jambi Malay customary marriage and want to know the Islamic legal review of giving customary money in Jambi Malay customary marriage in Jambi. The approach in this study is a qualitative normative sociological approach. In this study the authors used the type of field research (Field research), by conducting interviews with the local community, village heads, officials of the sharia ', traditional leaders, community leaders, religious scholars, and various parties needed information in writing this research. Based on the data obtained by the author in the field, after being reviewed and understood, the following research results are obtained, firstly that the position of giving customary money is a condition for the implementation of marriage and its nature is a mandatory gift from men to women and legal consequences. from giving customary money in Jambi Malay customary marriage depends on whether or not the man can fulfill the customary money which is determined by the female family, presumably able to fulfill the customary money then the marriage will be held and if the man is unable to fulfill the customary money then marriage and customary money will occur outside of the gift dowry. The two reviews of Islamic law on the giving of customary money do not violate the Qur'an and the Hadith, but there is a mistake in the community in determining the amount of customary money that is too high so that it is burdensome to the men.
\end{abstract}

Keywords: Customary Money, Customary Marriage, Islamic Law.

\begin{abstract}
Abstrak
Latar belakang masalah dalam penelitian ini adalah, di Jambi dalam upacara adat perkawinannya ada yang dinamakan uang adat (Selemak Semanis), yang uang adat ini adalah pemberian dari pihak laki-laki kepada perempuan yang akan dinikahi jika tidak terpenuhi uang adat ini maka tidak akan terjadi perkawinan.Adapun tujuan dari penelitian ini ingin mengetahui kedudukan dan akibat hukum pemberian uang adat dalam perkawinan adat melayu Jambi, ingin mengetahui akibat hukum dari pemberian uang adat dalam perkawinan adat melayu Jambi dan ingin mengetahui tinjauan hukum islam terhadap pemberian uang adat dalam perkawinan adat melayu Jambi di Jambi. Pendekatan dalam penelitian ini adalah pendekatan kualitatif normatif sosiologis. Dalam penelitian ini penulis menggunakan Jenis penelitian lapangan (Field research), dengan cara melakukan wawancara dengan pihak masyarakat setempat, kepala desa, pegawai syara', pemuka adat,
\end{abstract}

* Dosen Fakultas Syari'ah Universitas Islam Negeri (UIN) Sulthan Thaha Saifuddin Jambi. 
tokoh masyarakat, alim ulama, dan berbagai pihak yang dibutuhkan informasinya dalam penulisan penelitian ini. Berdasarkan data yang penulis peroleh di lapangan, setelah ditela'ah dan dipahami, diperolehlah hasil penelitian sebagai berikut, pertama yaitu kedudukan dari pemberian uang adat ini merupakan syarat agar terlaksananya pernikahan dan sifatmya merupakan pemberian wajib dari pihak laki-laki kepada pihak prempuan dan akibat hukum dari pemberian uang adat dalam perkawinan adat melayu Jambi tergantung kepada mampu atau tidak pihak laki-laki memenuhi uang adat yang di tentukan keluarga perempuan, kiranya mampu memenuhi uang adat tersebut maka pernikahan akan dilaksanakan dan jika laki-laki tidak mampu memenuhi uang adat tersebut maka tidak akan terjadi pernikahan dan uang adat ini diluar dari pada pemberian mahar. Kedua tinjauan hukum Islam terhadap pemberian uang adat ini tidak menyalahi dari Al Qur'an dan Hadits hanya saja terdapat kekeliruan di masyarakat dalam menentukan jumlah uang adat yang terlampau tinggi sehingga memberatkan pihak laki-laki.

Kata Kunci : Uang Adat, Perkawinan Adat, Hukum Islam

\section{Pendahuluan}

Perkawinan merupakan titik awal dari terbentuknya kehidupan berumah tangga yang berkaitan dengan masa depan suami-istri dan dengan realitas pemikiran dan kehidupan masing-masing mereka. Oleh karena itu, kesuksesannya bergandengan dengan anggapan masing-masing mereka bahwa perkawinan merupakan suatu tahapan yang berbeda dengan tahapan sebelumnya bahkan sampai waktu pertunangan. ${ }^{1}$

Perkawinan adalah tahapan untuk memasuki suatu realitas dan menjalani kehidupan yang menghubungkan, antara yang satu dan yang lain, bukan hanya dalam tingkat fisik saja, tetapi juga pada tingkat spiritual, intelektual, dan cultural. Ia adalah kehidupan yang selalu menuntut kontak sepanjang siang, malam dan kombinasi penuh yang mempengaruhi selera (keinginan), kebutuhan, dan hubungan masing-masing mereka. ${ }^{2}$

Tujuan perkawinan menurut agama Islam ialah untuk memenuhi petunjuk agama dalam rangka mendirikan keluarga yang harmonis, sejahtera dan bahagia. Harmonis dalam menggunakan hak dan kewajiban anggota keluarga; sejahtera artinya terciptanya ketenangan lahir bathin disebabkan terpenuhinya keperluan hidup lahir dan bathinnya, sehingga timbullah kebahagiaan, yakni kasih sayang antar anggota keluarga. ${ }^{3}$ Jadi aturan perkawinan menurut Islam merupakan tuntutan agama yang perlu mendapat perhatian, sehingga tujuan melangsungkan perkawinan pun hendaknya ditujukan untuk memenuhi petunjuk agama. Sehingga kalau diringkas ada dua tujuan orang melangsungkan perkawinan ialah memenuhi nalurinya dan memenuhi petunjuk agama. ${ }^{4}$

${ }^{1}$ Lukman Hakim, Membina Keluarga Sakinah. (Jambi: BP4 2012), hlm. 1.

${ }^{2}$ Ibid, hlm. 25

${ }^{3}$ Baharuddin Ahmad dan Fauzi Muhammad Nikah Beda Agama Di Indonesia, cet. Ke-1, (Ciputat: Referensi, 2013), hlm. 28.

${ }^{4}$ Ibid. 
Sudah menjadi sunnatulllah bahwa segala yang ada di dunia ini diciptakan oleh Allah SWT dalam keadaan berpasang-pasangan, begitu juga dengan manusia yang diciptakan oleh Allah SWT. ${ }^{5}$ Firman Allah dalam surah Yasin ayat 36:

"Maha Suci Tuhan yang telah menciptakan pasangan-pasangan semuanya, baik dari apa yang ditumbuhkan oleh bumi dan dari diri mereka maupun dari apa yang tidak mereka ketahui." 6

Tujuannya untuk mengikat kedua jenis insan ini dalam suatu ikatan yang sah, maka disyariatkanlah perkawinan sebagai suatu lembaga kehidupan yang resmi melalui akad nikah. Firman Allah dalam surah Az-Zariyat ayat 49:

"Dan segala sesuatu Kami ciptakan berpasang-pasangan supaya kamu mengingat kebesaran Allah." 7

Di dalam ayat dijelaskan bahwasannya seorang makhluk yang diciptakan oleh Allah SWT, berpasang-pasangan inilah yang menciptakan manusia menjadi berkembang biak dan berlangsung dari generasi ke generasi. ${ }^{8}$ Firman Allah SWT dalam Surah An-Nisa ayat 1:

"Hai sekalian manusia, bertakwalah kepada Tuhan-mu yang telah menciptakan kamu dari seorang diri, dan dari padanya Allah menciptakan isterinya; dan dari pada keduanya Allah memperkembang biakkan laki-laki dan perempuan yang banyak. dan bertakwalah kepada Allah yang dengan (mempergunakan) nama-Nya kamu saling meminta satu sama lain[264], dan (peliharalah) hubungan silaturrahim. Sesungguhnya Allah selalu menjaga dan mengawasi kamu".

Perkawinan merupakan salah satu unsur yang sangat penting dan merupakan suatu unsur yang akan meneruskan kelangsungan kehidupan manusia dan masyarakat di bumi ini. Perkawinan menyebabkan adanya keturunan dan keturunan akan menimbulkan keluarga yang nantinya akan berkembang menjadi kerabat dan masyarakat, oleh karena itu keberadaan ikatan sebuah perkawinan perlu dilestarikan demi tercapai tujuan yang dimaksudkan dalam perkawinan itu sendiri. ${ }^{9}$

Perkawinan itu sendiri dalam ketentuan Undang-Undang No 1 pasal 1 Tahun 1974 tentang undang-undang perkawinan yang selanjutnya disingkat menjadi UUP, perkawinan didefinisikan sebagai ikatan lahir batin antara seorang pria dengan seorang wanita sebagai suami istri dengan tujuan membentuk

${ }^{5}$ Tim Penyusun. Bidang Studi Syari'ah. (Jakarta: Bagian Proyek Peningkatan Mutu Madrasah Aliyah, 1984), hlm 3.

${ }^{6}$ Yasin (36): 36.

${ }^{7}$ Az-Zariyat (51): 49.

${ }^{8}$ Amir Syarifuddin. Hukum Perkawinan Islam di Indonesia antara Fiqh Munakahat dan UndangUndang Perkawinan.(Jakarta: Kencana Prenada Media Group, 2009), hlm 59.

${ }^{9}$ Amir Syarifuddin. Hukum Perkawinan Islam di Indonesia antara Fiqh Munakahat dan UndangUndang Perkawinan, hlm 60. 
keluarga (rumah tangga) yang bahagia dan kekal berdasarkan Ketuhan Yang Maha Esa. ${ }^{10}$

Adapun dalam perkawinan terdapat beberapa unsur yang harus terpenuhi demi kelancaran perkawinan tersebut, diantaranya rukun dan syarat.Rukun dan syarat menentukansuatu perbuatan hukum, terutama menyangkut terkait sah atau tidaknya perbuatan tersebut dari segi hukum. Kedua kata tersebut mengandung arti yang sama dalam hal bahwa kduanya merupakan sesuatu yang harus terpenuhi.

Dalam suatu perkawinan umpama rukun dan syaratnya tidak boleh tertinggal, dalam arti perkawinan tidak sah apabila keduanya tidak ada atau tidak lengkap. Keduanya mengandung arti yang berbeda di dalam hakikat dan merupakan bagian atau unsur yang mewujudkannya, sedangkan syarat adalah sesuatu yang berada diluarnya dan tidak merupakan unsurnya. Syarat itu ada yang berkaitan dengan rukun dalam arti syarat yang berlaku untuk setiap unsur yang menjadi rukun. ${ }^{11}$

Adapula syarat itu berdiri sendiri dalam arti tidak merupakan kriteria dari unsur-unsur rukun. Dalam hal hukum perkawinan dalam menempatkan mana yang rukun dan mana yang syarat terdapat perbedaan dikalangan ulama yang perbedaan ini tidak bersifat substansial. Perbedaan pendapat tersebut oleh karena berbeda dalam melihat fokus perkawinan itu sendiri. Semua ulama berpendapat dalam hal-hal yang terlibat dan yang harus ada dalam suatu perkawinan adalah: akad perkawinan, laki-laki yang akan kawin, perempuan yang akan kawin, wali dari perempuan, saksi yang menyaksikan akad perkawinan dan mahar atau maskawin. ${ }^{12}$

Dalam perkawinan masyarakat adat melayu Jambi di Kabupaten Muara Jambi ada istilah yang dikenal dengan adanya uang adat dimana uang adat ini diberikan kepada calon mempelai wanita. Pemberian uang adat ini sudah menjadi syarat (wajib dalam melaksanakan perkawinan adat melayu Jambi di Kabupaten Muara Jambi. Sebagaimana halnya yang di ungkapkan Amrullah selaku kepala Adat Melayu Muara Jambi, beliau menuturkan:

"Sebelum melaksanakan pernikahan biasanya di tempat kita ini ada namanya pemberian uang adat dari mempelai laki-laki kepada mempelai wanita dimana pemberian uang adat ini merupakan suatu kawajiban bagi mempelai laki-laki terhadap mempelai wanita pemberian uang adat Ini belum termasuk Mahar"13

Dari penjelasan di atas dapat disimpulkan bahwa dalam perkawinan adat melayu di Kabupaten Muara Jambi mempelai laki-laki harus memenuhi uang adat yang telah ditentukan oleh pihak keluarga mempelai wanita ditambah lagi

${ }^{10}$ Abdul Ghofur dan Yulkarnain Anshori, Hukum Islam Dinamika dan Perkembangannya di Indonesia (Yogyakarta: Kreasi Total Media, 2008), hlm 213.

${ }^{11}$ Ibid., hlm 60

${ }^{12}$ http://id.m.wikipedia.org/wiki/Jambi. Diakses 14 februari 2018 2:58pm

${ }^{13}$ Wawancara dengan Amrullah, Kepala Adat Kabupaten Muara Jambi, 27 Januari 2018 
pemberian mahar yang secara syariat merupakan suatu hal yang juga wajib bagi mempelai laki-laki untuk ditunaikan.

Dalam wawancara dengan Solihin, beliau menceritakan:

"Proses perkawinan di daerah kita ini menurut saya sangat sulit dikarnakan bagi kita khususnya laki-laki kita harus mengeluarkan biaya yang besar apabila hendak melaksanakan perkawinan terlebih lagi kewajiban mengeluarkan Uang Adat, jika Uang Adat ini tidak terpenuhi spontan kita tidak akan bisa melaksanakan perkawinan belum lagi maharnya, biaya-biaya yang lain sehingga menurut saya ini sangat menyulitkan"14

Dari penjelasan diatas bahwa masyarakat di daerah tersebut beranggapan bahwa membayar uang adat merupakan suatu kawajiban, sama halnya dengan kawajiban memberi mahar, dan jika uang adatini tidak ditunaikan maka pernikahan tidak akan terjadi. Dalam penentuan uang adat ini terkadang karena tingginya jumlah yang di patok menyebabkan seseorang gagal untuk menikah.

Melihat tingginya jumlah uang adat yang dikeluarkan dalam perkawinan di Kabupaten Muara Jambi sebaiknya uang mahar yang merupakan kewajiban dalam Islam tidak di permasalahkan jumlahnya, tergantung kerelaan dari pada mempelai laki-laki. Kebiasaan seperti inilah yang terjadi di Kabupaten Muara Jambi yang telah lama secara turun-temurun dilaksanakan sampai pada saat ini. Padahal hakikatnya dalam Islam tidak ada perintah mewajibkan memberi uang adat, kewajiban dalam Islam yang ada hanyalah memberikan mahar kepada si calon isteri.

\section{Kedudukan Dan Akibat Hukum Pemberian Uang Adat (Selemak Semanis) Dalam Perkawinan Adat Melayu Jambi}

Proses Perkawinan pada setiap daerah selalu menjadi hal yang sangat menarik untuk dibahas, baik dari segi latar belakang budaya perkawinan tersebut, maupun dari segi kompleksitas perkawinan itu sendiri. Karena dalam berlangsungnya sebuah perkawinan bukan hanya sekedar menyatukan dua insan yang saling mencintai. Lebih dari itu, ada nilai-nilai yang tak lepas untuk dipertimbangkan, seperti status sosial, ekonomi, dan nilai-nilai budaya dari masing-masing keluarga pria dan wanita.

Pada dasarnya Islam sangat menganjurkan kepada umatnya yang sudah mampu untuk menikah. Indonesia merupakan negara yang masyarakatnya sangat multietnis berbagai budaya dan suku di dalamnya sehingga menimbulkan suatu aturan atau hukum yang berbeda pula. Demukian dalam hal perkawinan mempunyai ketentuan dan peraturan dalam pelaksanaannya menurut hukum adat melayu Jambi bahwa ada beberapa tahap dalam perkawinan. ${ }^{15}$

\footnotetext{
${ }^{14}$ Wawancara dengan Solihin. Masyarakat Kabupaten Muara Jambi, 28 Januari.2018

${ }^{15}$ Muhammad Sibawaihi dan Mokhammad Baharun, 2017,"Adat Pernikahan Melayu Jambi Perspektif ‘Urf Dalam Ilmu Ushul Fiqh” Vol 1 No. 2, hal 167-168. Di akses 31 Agustus 2018.
} 
Di Kabupaten Muara Jambi terdapat beberapa tahapan sebelum perkawinan dilaksanakan, ada pun tahap-tahap tersebut sebelum melaksanakan pernikahan dimulai dari berusik sirih begurau pinang (masa perkenalan), betanyo (tahap pengamatan), tegak betuik duduk betanyo (masa berunding kedua belah pihak/bertunang/melamar), bayar adat sekaligus hantaran dan akad nikah, beratam (kedua mempelai membaca Al qur'an dimulai dari surah Adhu ha sampai surah An nas), resepsi (walimah/pesta). ${ }^{16}$

Uang adat (uang hantaran) adalah biaya berupa uang yang diserahkan oleh pihak laki-laki kepada pihak perempuan yang besarnya sesuai kesepakan kedua belah pihak untuk digunakan dalam acara perkawinan. Keberadaan uang belanja ini dijadikan sebagai salah satu syarat penting dalam menentukan dapat tidaknya dilaksanakan perkawinan dan selalu terkait dengan wibawa keluarga mempelai. Besarnya uang belanja menjadi merupakan pencerminan status sosial calon pengantin. Semakin tinggi status sosial wanita maka semakin besar uang belanja yang di keluarkan mempelai laki-laki. Hal ini menjadi masalah tersendiri dalam masyarakat, sebab tidak jarang terjadi pembatalan perkawinan yang disebabkan oleh tidak disepakatinya uang belanja oleh pihak perempuan. ${ }^{17}$

Tatacara perkawinan sebagaimana yang dimaksud di atas, tentunya menempatkan faktor ekonomi dan sosial sebagai suatu faktor penting yang turut menentukan bagi kelangsungan pelaksanannya. Dan mengingat kemampuan setiap individu masyarakat berbeda-beda terkadang menyediakan uang belanja yang menjadi suatu masalah pokok yang tidak jarang menjadi batu sandungan dalam mempersatukan tali kasih anak-anak manusia menuju kebahagiaan yang dicita-citakan.

Banyak tahapan pendahuluan yang harus dilewati sebelum pesta perkawinan (walimah) dilangsungkan khususnya di kelurahan pelabuhan dagang dari proses perkawinan secara umum, yaitu:

1. Masa perkenalan (berusik sirih begurau pinang)

Perkenalan laki-laki dengan perempuan untuk menyampaikan rasa cinta kasih sayang hingga menimbulkan keseriusan dalam sebuah hubungan dengan memakai seloko adat "adat bersendikan syara' dan syara' bersendikan kitabullah" serta "syara' mengato adat memakai".

\section{Masa pengamatan (betanyo)}

Dimana pihak dari seorang laki-laki mengutus umaik datang kerumah si wanita bertanya mengenai apakah anak dari keluarga si wanita telah dipinang seseorang atau belum, jikalau sudah maka utusan tadi atau umaik kembali dan

${ }^{16}$ Wawancara dengan Amrullah, Kepala Adat di kabupaten Muara Jambi, 31 Agustus 2018.

${ }^{17 N u r w a h i d a ~ d a n ~ L e s t a r i, ~ 2014, ~ “ K e d u d u k a n ~ S o m p a ~(M a h a r) ~ d a n ~ u a n g ~ b e l a n j a ~ d a l a m ~}$ perkawinan adat bugis di Kelurahan pasir putih Kecamatan Sinjai Borong Kabupaten Sinjai" Vol 1 No. 2. 
tidak melanjutkan hajatnya. Namun jika wanita tadi belum dipinang maka umaik akan berundung dan menentukan waktu lamaran setelah itu pulang dan melanjutkan kembali ke tahap tegak betuik duduk betanyo.

\section{b. Masa berunding / melamar (tegak betuik duduk betanyo)}

Masa berunding merupakan dimana pihak dari pada mempelai laki-laki mengutus juru bicara para waris dari saudara ibu (menti/umaik)untuk meninjau kepada pihak keluarga si gadis dan tidak lupa membawa tepak (tempat sirih) dengan tujuan untuk melanjutkan dari rundingan sebelumnya. Dalam acara rundingan yang dihadiri umaik dari kedua belah pihak serta kepala adat sebagai penengah, umaik dari pihak laki-laki membawa 10 kain sarung dan uang yang nantinya digunakan sebagai panjar awal uang adat. Disinlah kedua belah saling berunding menentukan berapa uang adat yang di tetapkan dari pihak wanita kepada pihak laki-laki. Setelah berunding dan uang adat telah di tetapkan maka pihak dari laki-laki (umaik) menyerahkan 10 kain sarung serta panjaran uang adat. Misalkan pihak wanita meminta uang adat 35 juta sedangkan saat itu pihak laki-laki membawa uang 5 juta maka pihak wanita menentukan waktu pelunasan uang adatnya, penyerahan sisa 30 juta tadi dilaksanakan saat akad nikah. Hal tersebut bisa terlaksa jika pihak laki-laki menyanggupi uang adat dengan tempo yang di tentukan tadi, namun jika batas waktu yang ditentukan telah lewat dan pihak laki-laki tidak mampu membayar maka gagallah acara pernikahan yang akan dilaksanakan. Jikalau dalam masa rundingan diatas jika pihak wanita meminta uang adat dengan jumlah yang telah ditentukan dan pihak laki-laki tidak sanggup menunaikannya maka gagal/batal untuk melaksanakan pernikahan. ${ }^{18}$

c. Membayar uang adat, hantaran dan akad nikah

Setelah acara adat diatas dilaksanakan maka dilanjutkan dengan acara adat membayar uang adat, hantaran dan akad nikah. Proses ini dilaksanakan dengan hadirnya rombongan calon pengantin laki-laki dengan membawa uang adat yang telah disepakati diawal, uang adat ini harus di perlihatkan dihadapan masyarakat banyak agar masyarakat tau bahwa laki-laki dan perempuan telah mengkuti adat setempat, setelah masyarakat tau bahwa benar uang adat yang dibawa sudah sesuai kesepakan maka diserahkan uang adat tersebut kepada pihak wanita, barang-barang hantaran berupa baju, sprey, alat-alat mandi, sepatu, kosmetik dan lain-lain biasanya barang hantaran tersebut dibentuk sedemikian rupa ada berbentuk hewan angsa, masjid, bunga dan banyak lagi dan semua itu diserahkan juga kepada mempelai wanita. Setelah selesai baru dilaksanakan akad nikah menurut syara'.

5. Membaca Al qur'an Surah Adhuha sampai An nas (beratam)

${ }^{18}$ Wawancara dengan Amrullah, Ketua adat kabuaten Muara Jambi 31-Agustus 2018.

Volume 1, Nomor 1, Juni 2019 
Setelah semua rangkaian tersebut dilaksanakan mempelai laki-laki dan perempuan melaksanakan khataman dengan membaca Al qur'an yang dimulai dari surah Adduha sampai Annas.

\section{Resepsi ( walimah/pesta)}

Setelah akad nikah maka dilaksanakan resepsi dimana para tamu undangan beramai-ramai datang untuk memberikan do'a restu sekaligus menjadi saksi behwa kedua pengantin ini telah resmi menjadi suami istri. ${ }^{19}$

Uang adat bermakna pemberian uang dari pihak keluarga laki-laki kepada pihak keluarga perempuan sebagai suatu penghormatan. Penghormatan yang dimaksud disini adalah rasa penghargaan yang diberikan oleh mempelai pria kepada wanita yang ingin dinikahinya dengan memberikan pesta yang megah untuk pernikahannya melalui uang atau uang belanja tersebut. Selain itu uang adat juga digunakan sebagai kebutuhan bersama dalam perkawinan. ${ }^{20}$

Agama Islam sebagai agama Rahmatan lil alamin tidak menyukai penentuan mahar yang memberatkan pihak laki-laki untuk melangsungkan perkawinan, demikian pula terhadap uang adat. Perkawinan sebagai sunnah Nabi hendaknya dilakukan dengan penuh kesederhanaan dan tidak berlebihlebihan.

Sebagaimana Sabda Nabi SAW, dari Hafs Usamah bin Kamal bin Abdil Razak:

"artinya adakanlah Walimah walau dengan seekor kambing"

Al qur'an surah Azzumar: 53

"Katakanlah: "Hai hamba-hamba-Ku yang malampaui batas terhadap diri mereka sendiri, janganlah kamu berputus asa dari rahmat Allah. Sesungguhnya Allah mengampuni dosa-dosa semuanya. Sesungguhnya Dialah Yang Maha Pengampun lagi Maha Penyayang." 21

Dari penjelasan Rasul diatas bahwa menikah tidak perlu mewah bahkan walimah bisa saja dengan 1 ekor kambing, dalam Firman Allah diatas juga menekankan agar menjaga diri kita dari sifat yang melampai batas. Firman Allah dalam $\mathrm{Al}$ qur'an surah $\mathrm{Al}$ isra: 26-27:

"dan jangnlah kamu menghambur-hamburkan (harta)mu secara boros, sesungguhnya pemboros-pemboros itu adalah saudara syaitan".22

Bahkan Rasul SAW memerintah seorang muslim yang apabila telah mampu agar segera menikah. Keluarga merupakan inti dari masyarakat Islam dan dengan menikah merupakan cara untuk membentuknya. Sedangkan hubungan diluar itu merupakan hal yang keji:

"Dan janganlah kamu mendekati zina, sesungguhnya zina itu adalah suatu perbuatan yang keji dan suatu jalan yang buruk. ${ }^{23}$

${ }^{19}$ Hasan Basri Agus, Iktisar Adat Melayu Kota Jambi,( Jambi: Tim POKJA 2004), halaman 49.

${ }^{20}$ Wawancara dengan Andi masyarakat Kabupaten Muara Jambi, 31 Agustus 2018.

${ }^{21} \mathrm{Az}-$ Zumar (39): 53

${ }^{22} \mathrm{Al}$ Isra'(17): 26-27

${ }^{23} \mathrm{Al}$ Isra' (17): 32 
Tinggi rendahnya uang adat yang ada di Kelurahan Pelabuhan Dagang Sendiri di pengaruhi beberapa faktor diantaranya: ${ }^{24}$

\section{Status Ekonomi}

Semakin kaya wanita yang akan dinikahi maka semakin besar pula uang adat yang di keluarkan oleh mempelai laki-laki. Terkadang dikarenakan status ekonomi pihak wanita yang mapan tidak jarang pihak wanita meminta uang adat yang begitu tinggi, dan tidak jarang karena permintaan uang yang tinggi itu pihak laki-laki mundur atau gagal menikah.

\section{Tingginya pendidikan}

Di kelurahan pelabuhan dagang sendiri wanita-wanita yang telah menyelesaikan pendidikan pada jenjang yang tinggi akan sangat memengaruhi jumlah dari uang adat itu sendiri. Mereka beralasan bahwa uang adat yang besar itu sepadan terhadap dengan gelar sarjana yang anak mereka sandang. Tak ayal pihak wanita meminta uang adat sangat besar kepada pihak laki-laki.

Dampak lain akibat tingginya uang adat adalah munculnya semangat kerja bagi para lelaki yang ingin menikahi wanita pilihannya. Sehingga wanita yang benar-benar dicintainya akan menjadi motivasi yang sangat besar bagi lakilaki untuk memenuhi jumlah uang adat yang disayaratkan. Motivasi dapat diartikan sebagai faktor pendorong yang berasal dari dalam diri manusia dalam hal ini untuk menunaikan uang adat tersebut, yang kemudian akan mempengaruhi cara bertindak seseorang.

Tetapi tidak dapat dipungkiri bahwa tingginya jumlah uang adat yang dipatok pihak keluarga pihak wanita mengakibatkan terjadinya pembatalan perkawinan, renggangnya hubungan kedua belah pihak dan kadang pihak mempelai nekat kawin lari karena tidak dapat bersama dalam tali pernikahan. Semua itu terjadi jika pihak laki-laki tidak mampu memenuhi uang adat yang di patok pihak wanita. Jadi disisi lain, terdapat dampak positif dan negatif dari tingginya uang belanja tersebut. Pada akhirnya disadari atau tidak, bahwa tidak hanya pihak keluarga perempuan yang ditinggikan derajatnya akan tetapi keluarga calon mempelai laki-laki juga berhasil mempertegas kedudukannya dengan kemampuannya memenuhi prasyarat uang belanja yang tidak sedikit jumlahnya atau diatas kemampuan rata-ratanya. ${ }^{25}$

Adapun akibat hukum jika pihak laki-laki tidak mampu menyanggupi julah uang adat yang di tawarkan pihak wanita, maka secara otomatis perkawinan akan batal. Tentu konsekwensi dari batalnya pernikahan itu tidak jarang akan menjadi buah bibir masyarakat setempat. Bahkan kita sendiripun tau pada dasarnya perkawinan yang dilaksanakan untuk menyempurnakan separuh agama serta terciptanya mashalahat antara kedua belah mempelai.

\footnotetext{
${ }^{24}$ Wawancara dengan Yuli masyarakat Kabupaten Muara Jambi, 1 September 2018.

${ }^{25}$ Nurul Hikmah, 2015, "Problematika Uang Belanja Pada Masyarakat di Desa Balangpesoang Kecamatan Bulukumpa Kabupaten Bulukumba", Vol. 2 No. 3, http://ojs.unm.ac.id/index.php/tomalebbi/article/view/1853. Di akses pada 7 November 2017.
} 
Lebih lanjut penjelasan oleh Abdul Rahman, bahwa dalam konsep Maqasid al-syariah diharapkan segala sesuatu yang dikerjakan oleh manusia tidak lepas dari kemaslahatan manusia itu sendiri dan manusia disekitarnya. Oleh karena itu, segala hal yang tidak sejiwa dengan tujuan perbuatan baik itu haruslah dihindari. Demikian juga dalam hal perkawinan ini, haruslah dijaga kemaslahatannya bagi orang yang melaksanakannya dan keturunannnya. Segala sesuatu yang menyebakan timbulnya kemudharatan dari perkawinan itu haruslah dihindari, sebagaimana sabda Rasullullah SAW dilarang menimbulkan kemudharatan pada diri sendiri maupun pada orang lain.

Tujuan perkawinan menurut agama Islam ialah untuk memenuhi petunjuk agama dalam rangka mendirikan keluarga yang harmonis, sejahtera dan bahagia. Harmonis dalam menggunakan hak dan kewajiban anggota keluarga, sejahtera artinya terciptanya ketenangan lahir dan batin disebabkan terpenuhinya keperluan hidup lahir dan batinnya, sehingga timbullah kebahagianan, yakni kasih sayang antar anggota keluarga.

Manusia diciptakan Allah SWT mempunyai naluri manusiawi yang perlu mendapat pemenuhan. Pemenuhan naluri manusiawi manusia yang antara lain keperluan biologisnya termasuk aktivitas hidup, agar manusia menuruti tujuan kejadiannya, Allah SWT mengatur hidup manusia dengan aturan perkawinan.

Melihat dua tujuan diatas dan memperhatikan uraian Imam Al-Ghazali dalam Ihyanya tentang faedah melangsungkan perkawinan, maka tujuan perkawinan dapat dikembangkan menjadi lima yaitu:

1. Mendapatkan dan melangsungkan keturunan

2. Memenuhi hajat manusia untuk menyalurkan syahwatnya panggilan dan menumpahkan kasih sayangnya.

3. Memenuhi panggilan agama, memelihara diri dari kejahatan dan kerusakan.

4. Menumbuhkan kesungguhan untuk bertanggung jawab menerima hak serta kewajiban, juga bersungguh-sungguh untuk memperoleh harta kekayaan yang halal.

Membangun rumah tangga untuk membentuk masyarakat yang tenteram atas dasar cinta dan kasih sayang. ${ }^{26}$

Dalam tinjauan fiqh, kemaslahatan merupakan tujuan yang akan dicapai. Sebagai sebuah tujuan, tentu kemaslahatan tidak dapat dicapai begitu saja tanpa melalui suatu proses hukum yang dijalankan secara Syar'i. Karena berdasarkan kaidah, apabila syariat dijalankan pasti akan timbul kemaslahatan baik di dunia maupun di akhirat. Begitu pula dengan pernikahan, agar tujuannya dapat dicapai tentu membutuhkan proses yang baik dengan mengikuti peraturan yang berlaku. ${ }^{27}$ hlm $22-24$

${ }^{26}$ Abdul Rahman Ghozali. Fiqh Munaqahat. (Jakarta: Kencana Prenada Media Group, 2008),

${ }^{27}$ Baharuddin Ahmad dan Yuliatin, Hukum Perkawinan Umat Islam Indonesia Perspektif Figh Munakahat \& Undang-Undang Perkawinan., hlm 76-77. 


\section{Tinjauan Hukum Islam Terhadap Uang Adat (Selemak Semanis) Dalam Perkawianan Adat Melayu Jambi}

Hukum dan perubahan masyarakat adalah suatu hal yang sangat menarik dan layak ditekuni, apalagi bagi seorang, badan atau lembaga yang selalu berkecimpung di bidang hukum. Apabila diperhatikan citra hukum yang selalu ingin mencari dan memberikan kepastian hukum maka banyak sekali aspek keterlibatan hukum itu mempengaruhi masyarakat. Sebaliknya, bila terjadi perubahan dalam masyarakat maka perubahan turut membentuk perkembangan hukum, karena hukum itu berkembang dan berubah maka masyarakat turut berubah dan berkembang. Disamping itu, perkembangan hukum tidak lepas dari perubahan politik, sosial, dan budaya. Dengan demikian, kita terpaksa berbicara hukum yang terpasang ditengah-tengah masyarakat, agar kita bisa mengawasi bagaimana hukum mempunyai dampak dengan persoalan yang mengelilinginya. ${ }^{28}$

Islam mengajarkan kepada kita dalam pemberian pemberian mahar tidak ada kadar khusus, mahar wajib diberikan kepada calon mempelai wanita walaupun hanya sebuah cincin dari besi dan hafalan Qur'an. Dalam kata lain mahar diberikan sesuai kemampuan dan kerelaan dari kedua belah pihak.

Sebagaimana Hadist Rasul SAW yang diriwatkan Ahmad:

"dianatara kebaikan wanita ialah memudahkan maharnya dan memudahkan rahimnya"

Demikian juga sabda Rasul SAW, yang di riwayatkan Bukhari:

"carilah sekalipun cincin yang terbuat dari besi"

Dari penjelasan beberapa hadits diatas bisa kita ketahui bahwa pemberian mahar kepada mempelai wanita merupakan suatu hal yang wajib di tunaikan oleh mempelai laki-laki, terbukti dengan jenis mahar yang di berikan hanya berupa cincin yang terbuat dari besi dan sifatnya murah serta tidak memberatkan, berbeda dengan pemberian uang adat yang sifatnya tidak diatur secara rinci dalam Nash akan tetapi secara adat wajib ditunaikan.

Besarnya uang adat/uang belanja ditentukan oleh keluarga pihak perempuan, pada saat ini sering kita temui bahwa orang tua dari pihak wanita mengukur uang adat dari status sosial dan tingginya tingkat pendidikan. Ada juga sebagian masyarakat yang mengukur masalah kafa'ah dari agamanya, yaitu akhlaknya, istiqomah dan budi pekertinya. Sebagaimana dalam Al qur'an surah $\mathrm{Al}$ hujarat ayat 13:29

"Hai manusia, sesungguhnya Kami menciptakan kamu dari seorang

laki-laki dan seorang perempuan dan menjadikan kamu berbangsa-

bangsa dan bersuku-suku supaya kamu saling kenal-mengenal.

\footnotetext{
${ }^{28}$ Mohd. Idris Ramulyo. Asas-Asas Hukum Islam (Sejarah Timbul dan Berkembangnya Kedudukan Hukum Islam dalam Sistem Hukum di Indonesia)”. (Jakarta: Sinar Grafika, 2004), hlm 84.

${ }^{29}$ Ali Said, 2016,“Studi Perbandingan Tentang Kafa'ah Dalam Hukum Islam dan Budaya Bugis Bone", Vol. 2 No. 1
} 
Sesungguhnya orang yang paling mulia diantara kamu disisi Allah ialah orang yang paling takwa diantara kamu. Sesungguhnya Allah Maha Mengetahui lagi Maha Mengenal." $" 30$

Hakikatnya memang tidak ada penentuan hukum terhadap uang adat dalam perkawinan di daerah kita ini, akan tetapi tetap menjadi faktor penting karena tradisi tersebut dianggap tidak menyalahi dan bertentangan terhadap $\mathrm{Al}$ qur'an dan Hadits Rasulullah SAW, demikian halnya tentang uang adat yang berlaku di sini (Kabupaten Muara Jambi), hanya di anggap pemberian semata atau bersifat hadiah dari mempelai laki-laki kepada mempelai perempuan. Karena tidak dianggap bertentangan dan dalam proses pelaksanaan adatnya lebih mengutamakan unsur keridhoan dan kesepakatan dari kedua belah pihak. Tradisi uang adat di kelurahan pelabuhan dagang ini dipandang sebagai Urf' shahih (sah) karena hukum itu berlaku pada 'illat, zaman dan tempat. Dan itu dimaklumi karena prinsip Islam itu ada pada pernikahan itu sendiri sedangkan uang adat berada pada prinsip hukum adat. ${ }^{31}$

Urf ialah segala sesuatu yang sudah dikenal diantara manusia yang telah menjadi kebiasaan atau tradisi baik bersifat perkataan, perbuatan, atau dalam kaitannya dengan meninggalkan perbuatan teretentu, sekaligus disebut sebagai adat. Begitu pula dengan Urf shahih ialah segala sesuatu yang sudah dikenal umat manusia yang tidak bertentangan dengan dalil syara', disamping tidak menghalalkan yang haram dan tidak menggugurkan kewajiban. Untuk Urf shahih haruslah dilestarikan dalam kaitannya dengan upaya pembentukan hukum dan proses peradilan. ${ }^{32}$

Tradisi uang adat adat dalam konsep perkawinan adat melayu Jambi, jumlah uang adat memang ditentukan oleh pihak wanita. Namun dari pandangan hukum uang adat masuk sebagai hadiah dan terserah kepada pihak laki-laki sebagai pemberi hadiah. Oleh karena itu untuk mempertemukan dua perspektif yang berbeda maka uang adat tidak di hilangkan akan tetapi jumlahnya tergantung pada kesepakatan kedua belah pihak dengan prinsip saling memudahkan. ${ }^{33}$

Sebagaimana mestinya harus dibayarkanlah kepada wanita-wanita yang ingin kalian nikahi mahar-mahar mereka sebagai suatu pemberian yangdiwajibkan yang tidak dapat diganti. Syariat tidak dapat menentukan ukuran tertentu dari suatu mahar, karena tingkat kekayaan dan kemiskinan orang itu berbeda-beda. Ada orang yang mampu memberikan mahar yang banyak dan ada juga yang tidak manpu. Lagi pula agama itu dibangun untuk memberikan kemudahan, bukan untuk menyulitkan. Di dalam mazhab

${ }^{30} \mathrm{Al}$ - Hujurat (49): 13

${ }^{31}$ Wawancara dengan . H. Zaini sebagai Pemuka Agama di Kabupaten Muara Jambi. 2 September 2018.

${ }^{32}$ Abdul Rahman dan Ahmad Rofiq, Fiqih, (Bandung: CV. Armico, 1988), hlm 166-167.

${ }^{33}$ Wawancara dengan Nashardin seorang Masyarakat di Kabupaten Muara Jambi 2 September 2018. 
Malikiyah disebutkan bahwa batas terendah dari mahar adalah tiga dirham. Sebagian mazhab memandang bahwa batas terendah mahar adalah sepuluh dirham. Tidak ada batas maksimal dari mahar, karena ada firman Allah dalam Al qur'an surah an- nisa ayat 20

"sedang kamu telah memberikan kepada seseorang di antara mereka harta yang banyak"(QS. An-Nisa' (4): 20).

Walaupun demikian, makruh memberikan mahar yang terlalu besar yang sampai pada ukuran yang memberatkan suami. Karena, mahar yang terlalu besar dapat menyulitkan pernikahan, padahal pernikahan merupakan salah satu sunah Islam dan Rasulullah SAW telah mengatakan:

"Sesungguhnya pernikahan yang paling besar keberkahannya adalah yang paling ringan biayanya". ${ }^{34}$

Dalam Islam secara lengkap telah diatur mengenai sesuatu yang berkaitan dengan perkawinan, apalagi perkawinan yang diikat atas nama Allah yang akan dipertanggung jawabkan kepadanya. Sebagai salah satu bentuk akad atau transaksi, perkawinan dalam hukum Islam akan mengakibatkan adanya hak dan kewajiban antara pihak yang terkait, yaitu pasangan suami istri yang merupakan salah satu kewajiban suami yang merupakan hak istri adalah pemberian mahar atau mas kawin dari calon suami kepada calon istrinya.

Allah SWT berfirman:

"Berikanlah maskawin (mahar) kepada wanita (yang kamu nikahi) sebagai pemberian dengan penuh kerelaan. (QS. An-Nisa' (4): 4)". ${ }^{35}$

Dalam perkembangannya tradisi perkawinan dengan memakai uang adat bukan hanya ada pada satu daerah akan tetapi di beberapa daerah juga memakai uang adat namun dengan konsep dan bahasa yang berbeda Hantaran nikah atau sering disebut seserahan atau anteran, tukon (suku jawa), uang hantaran/uang adat/uang belanja (suku melayu), jujuran (suku banjar), mappandre duii / duii blanca (suku bugis), merupakan simbol persembahan seorang laki-laki kepada wanita yang ingin dinikahinya.

Berdasarkan adat tersebut, terdapat dua yang tidak dapat dipisahkan dalam proses perkawinan, yaitu dari pihak laki-laki tidak hanya memberikan mahar kepada calon istrinya, akan tetapi menurut ketentuan adat juga harus memberikan Uang adat. Uang adat dalam penikahan adat melayu Jambi di Kabupaten Muara Jambi adalah penyerahan harta terdiri dari uang atau harta yang besarnya diukur sesuai dengan stratifikasi sosial dalam masyarakat.

Contoh dalam perkawinan dilihat dari faktor Pendidikan dan strata sosial adalah sebagai berikut:

${ }^{34}$ Raana Bokhari, dkk., “ Bab Nikah," dalam Nasaruddin Umar dan Ali Nurdin (ed), Ensiklopedi Apa dan Mengapa dalam Islam, (Jakarta: Kalam Publika, 2009), hlm 811.

${ }^{35}$ An- Nisa' (4): 4 
ADHKI: Journal of Islamic Family Law

1. Toni menikahi Maya pada tahun 2017 dengan uang adat sebesar 50 juta faktor yang mempengaruhi tingginya uang adat adalah dikarenakan Maya adalah seorang sarjana kesehatan, selain itu Maya juga dikategorikan keluarga terpandang. Oleh karena keluarga Maya mematok dengan harga tinggi.

2. Faisal menikahi Umi pada tahun 2017 yang lalu dengan uang adat 50 juta besarnya uang adat yang di pinta dari keluarga Umi dikarenakan Umi seorang sarjana hukum.

3. Hendri menikahi Nina dengan Uang adat 35 juta lebih kecil di banding dari pernikahan diatas, faktor yang mempengaruhi tinggi uang adat adalah dikarenakan Nina adalah seorang dengan paras cantik. ${ }^{36}$

Penjelasan lebih lanjut mengenai uang adat dalam perkawinan adat melayu Jambi di Kabupaten Muara Jambi dikatakan oleh bapak Amrullah sebagai tokoh adat:

"Kalau kita lihat dalam prosesi uang adat pra nikah adat Jambi di Kabupaten Muara Jambi Ini sebenarnya telah sesuai dengan ketentuan syari'at dan adat itu sendiri boleh di terapkan asalkan tidak bertentangan dengan Al qur'an dan Hadits, hanya saja masih ada kekeliruan di kalangan masyarakat dalam penetapan jumlah uang adat yang terlampau tinggi oleh pihak wanita sehingga memberatkan pihak laki-laki selain uang adat yang besar di tentukan juga waktu kapan uang adat itu di serahkan jikadalam jangka waktu yang ditentukan tidak menyerahkan uang adat maka otomatis gagallah pernikahan tersebut dan dalam pandangan agama hal semacam ini terkesan ada ketentuanketentuan yang menyulitkan dalam melaksanakan titah agama (menikah). Pada dasarnya dalam penetapan uang adat lebih mengutamakan sisi agamanya seperti akhlak, budi pekerti sopan santun, tatacara bergaul dan lain sebagainya. ${ }^{37}$

Berdasarkan penjelasan diatas bahwa adanya prosesi uang adat dalam perkawinan adat melayu Jambi di Kabupaten Muara Jambi telah sesuai dengan ketentuan yang telah di syari'atkan dan adat itu boleh diterapkan dengan syarat tidak bertentangan dengan syari'at Islam. Hanya saja masih terdapat kekeliruan dalam penetapan jumlah uang adat sehingga memberatkan pihak pengantin lakilaki. Esensi yang terkandung dalam syariat perkawinan adalah mentaati perintah Allah SWT dan sunnah Rasul, yaitu yang menciptakan suatu kehidupan rumah tangga yang mendatangkan kemaslahatan, baik bagi pelaku perkawinan itu sendiri, anak, keturunan, kerabat maupun masyarakat. Oleh karena itu, perkawinan tidak hanya bersifat internal yang bersangkutan, tetapi mempunyai kaitan eksternal yang melibatkan banyak pihak. Sebagai suatu perikatan yang kokoh (mitsaqan ghalidzan), perkawinan dituntut untuk menghasilkan suatu

\footnotetext{
${ }^{36}$ Wawancara dengan Nurwinda Masyarakat Kabupaten Muara Jambi. 4 september 2018.

${ }^{37}$ Wawancara dengan Bapak Amrullah tokoh adat dan tokoh agama Kabupaten Muara Jambi. 4 September 2018
} 
kemaslahatan yang kompleks, bukan sekedar penyaluran kebutuhan biologis semata. ${ }^{38}$

Adapun dalam perkawinan terdapat beberapa unsur yang harus terpenuhi demi kelancaran perkawinan tersebut, diantaranya adalah rukun dan syarat.Rukun dan syarat menentukan suatu perbuatan hukum, terutama menyangkut dengan sah atau tidaknya perbuatan tersebut dari segi hukum. Kedua kata tersebut mengandung arti yang sama dalam hal bahwa keduanya merupakan sesuatu yang harus terpenuhi. Masalah hubungan hukum adat dengan hukum Islam, adat dapat dimasukkan asal tidak bertentangan dengan akidah hukum Islam.

Menurut T.M Hasbi Ash-Shidiqie, dalam bukunya Pengantar Hukum Islam: Urf atau adat itu sebagai salah satu alat atau metode pembentukan hukum Islam. Pernyataan ini sejalan dengan patokan pembentukan garis hukum: $A l$ adatu muhaksamat (muhakkamat), artinya adat dapat dijadikan hukum."Menurut Sobhi Muhmassani, agar dapat dijadikan hukum, syarat-syaratnya adalah sebagai berikut:

1. Adat itu diterima oleh perasaan, akal sehat, dan diakui oleh masyarakat umum.

2. Sudah dilakukan berulang kali dan telah berlaku umum dalam masyarakat.

3. Telah ada pada waktu transaksi dilangsungkan.

4. Tidak ada persetujuan lain antara kedua belah pihak.

5. Tidak bertentangan dengan nash Al-quranulkarim dan hadis Rasullullah SAW atau tidak bertentangan dengan syariat Islam. ${ }^{39}$

Hal tersebut sesuai dengan kaidah seperti berikut yaitu:

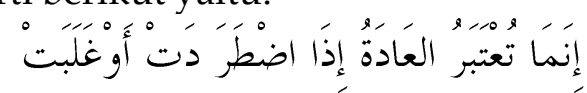

"Adat yang dianggap (sebagai pertimbangan hukum) itu hanyalah adat yang terus menerus berlaku atau berlaku umum".

Lebih lanjut dijelaskan dalam kaidah:

"Ketentuan berdasarkan 'urf seperti ketentuan berdasarkan nash". ${ }^{40}$

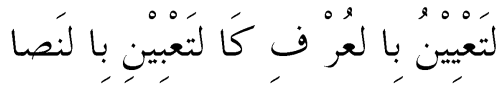

Pemberian uang adat merupakan tradisi yang bersifat umum, dalam artian berlaku untuk semua masyarakat di pelabuhan dagang. Walaupun pemberian uang adat tidak diatur secara gamblang dalam hukum Islam, namun pemberian uang adat sudah menjadi adat dan tradisi yang harus dilakukan pada

\footnotetext{
${ }^{38}$ Baharuddin Ahmad dan Yuliatin, Hukum Perkawinan Umat Islam Indonesia Perspektif Figh Munakahat \& Undang-Undang Perkawinan., hlm 16.

${ }^{39}$ Mohd. Idris Ramulyo, Asas-Asas Hukum Islam (Sejarah Timbul dan Berkembangnya Kedudukan Hukum Islam dalam Sistem Hukum di Indonesia)", hlm 34.

${ }^{40} \mathrm{Http}$ ///wardahcheche.blogspot.co.id/2013/11/kaidah-lima-asasi-ushul-fiqh.html.Di akses pada 29 November 2017.
} 
masyarakat tersebut dan selama ini tidak bertentangan dengan akidah dan syariat Islam maka hal ini diperbolehkan.

Maka adat tersebut dapat dijadikan pijakan sebagai suatu hukum Islam yang mengakui efektifitas adat istiadat dalam interpretasi hukum. Sebagaimana kaidah fiqhiyah yang berbunyi:

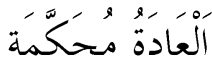

\section{"Adat kebiasaan dapat ditetapkan sebagai hukum". ${ }^{41}$}

Hukum dari pemberian uang adat menurut Islam adalah Mubah, tapi jika sudah masuk dalam adat maka hukumnya adalah wajib. Karena ada kaidah dalam hukum Islam. Hukum itu berputar sesuai dengan illat, keadaan dan massa.pemberian uang adat ini tidak diatur secara gamblang dalam hukum Islam, namun pemberian uang adat sudah merupakan suatu tradisi yang harus dilakukan pada masyarakat tersebut dan selama hal ini tidak bertentangan dengan akidah dan syariat maka hal itu diperbolehkan. ${ }^{42}$

Perlu dipertegas bahwa pelaksanaan perkawinan dalam adat Melayu Jambi di Kabupaten Muara Jambi yang berkaitan dengan uang adat, walaupun sudah menjadi tradisi dan membudaya hal ini tidak bersifat wajib, dalam artian perkawinan yang dilaksanakan tanpa memberikan uang adat dan hanya dengan memberikan mahar kepada calon mempelai wanita maka perkawinan tersebut tetap sah dalam hukum Islam, namun secara adat akan dianggap sebagai pelanggaran sanksi moral yang berakibat mendapatkan celaan dari masyarakat dan dikatakan tidak taat akan adat.

Tradisi pemberian uang adat juga sesuai dengan asas-asas hukum perkawinan Islam yang berlaku yang didalamnya juga terdapat asas kerelaan dan kesepakatan antara kedua belah pihak dalam hal penentuan jumlah uang adat.

\section{Penutup}

a. Kedudukan uang adat dalam perkawinan adat melayu Jambi di Kabupaten Muara Jambi adalah sebagai salah satu syarat mutlak yang harus dilakukan karena uang adatmerupakan pemberian wajib yang harus diberikan oleh pihak laki-laki kepada pihak perempuan yang akan digunakan sebagai modal untuk pesta perkawinan. Adapun dampak yang ditimbulkan akibat tingginya uang adat yaitu: batal menikah, hubungan antara kedua belah pihak menjadi renggang, terjadinya kawin lari, terjadinya perbuatan zina dan sebagainya.

Dampak lain akibat tingginya uang adat adalah munculnya semangat kerja bagi para lelaki yang ingin menikahi wanita yang benar-benar dicintainya akan menjadi motivasi yang sangat besar baginya untuk memenuhi jumlah

\footnotetext{
${ }^{41}$ Suhar.Kaidah-Kaidah Ushuliyah \& Fiqhiyah. (Jakarta: Referensi Gaung Persada Press Group, 2014), hlm 264.

${ }^{42}$ Wawancara dengan Munawir Zazali tokoh agama Kabupaten Muara Jambi 6 September 2018.
} 
uang adat yang disayaratkan. Jadi, disisi lain, terdapat dampak positif dan dampak negatif dari tingginya uang adat tersebut.

2. Tinjauan hukum Islam terhadap uang adat menjelaskan bahwa tidak ada ketentuan yang mengatur mengenai uang adat dalam Islam. Akan tetapi hukumnya mubah karena tidak ada dalil yang melarang, Hukum dari pemberian uang adat menurut Islam adalah mubah, tapi jika sudah masuk dalam adat maka hukumnya adalah wajib, Karena ada kaidah dalam hukum Islam. Hukum itu berputar sesuai dengan kondisi. Walaupun pemberian uang adat tidak diatur secara gamblang dalam hukum Islam, namun pemberian uang adat sudah merupakan suatu tradisi yang harus dilakukan pada masyarakat tersebut dan selama hal ini tidak bertentangan dengan akidah dan syariat maka hal itu diperbolehkan.

\section{Daftar Pustaka}

Abdul Ghofur dan Yulkarnain Anshori, Hukum Islam Dinamika dan Perkembangannya di Indonesia Yogyakarta: Kreasi Total Media, 2008

Abdul Rahman dan Ahmad Rofiq, Fiqih, Bandung: CV. Armico, 1988

Abdul Rahman Ghozali. Figh Munaqahat. Jakarta: Kencana Prenada Media Group, 2008

Abdurrahman. Kompilasi Hukum Islam di Indonesia. Jakarta: CV. Akademika Pressindo, 2007

Alaiddin Koto, Filsafat Hukum Islam. Jakarta: Raja Grafindo Persada, 2013

Amir Syarifuddin. Garis-Garis Besar Fiqh. Jakarta: Kencana Prenada Media Group, 2010

Amir Syarifuddin. Hukum Perkawinan Islam di Indonesia antara Figh Munakahat dan

Undang-Undang Perkawinan. Jakarta: Kencana Prenada Media Group, 2009

Amiruddin dan Zainal Asikin.Pengantar Metode Penelitian Hukum. Jakarta: PT. Raja Grafindo Persada, 2008

Anonim Al Qur'an dan terjemahan, Bandung: Hilal, 2009

Arikunto Siharsimi, Prosedur Penelitian suatu pendekatan Pratek, Yogyakarta: Rineka Cipta, 1997

b. Lain-lain

Baharuddin Ahmad dan Yuliatin. Hukum Perkawinan Umat Islam Indonesia Perspektif Figh Munakahat \& Undang-Undang Perkawinan. Jawa Barat: Launching Publishing Panorama Residence, 2015

Burhan Ashshofa, Metode Penelitian Hukum,Jakarta: Rineka Cipta, 2004

Hasan Basri Agus, Ikhtisar Adat Melayu Kota Jambi, Jambi: Tim POKJA 2004

Hasbi Umar. Filsafat Hukum Islam Kontemporer, Medan: Perdana Publishing, 2016

http://id.m.wikipedia.org/wiki/Jambi. Diakses 14 februari 2018 2:58pm

Husaini Usman dan Purnomo Setiady Akbar, metologi penelitian sosial, Jakarta:

Bumi Aksara, 2008 
ADHKI: Journal of Islamic Family Law

Husein Umar, Metode Penelitian untuk Skripsi dan Tesis Bisnis, Jakarta: Raja Grafindo Persada, 2011

Ishaq, Metode Penelitian dan Penulisan Skripsi, Tesis, serta Disertasi. (Kerinci: STAIN Kerinci Press, 2015

Mohd. Idris Ramulyo. Asas-Asas Hukum Islam (Sejarah Timbul dan Berkembangnya Kedudukan Hukum Islam dalam Sistem Hukum di Indonesia)".Jakarta: Sinar Grafika, 2004

Muhammad Amin Summa. Hukum Keluarga Islam di Dunia Islam.Jakarta: PT Raja Grafindo Persada, 2005

Raana Bokhari, dkk., "Bab Nikah," dalam Nasaruddin Umar dan Ali Nurdin (ed), Ensiklopedi Apa dan Mengapa dalam Islam, Jakarta: Kalam Publika, 2009

Romdhoni. Best Guide Project Skripsi, Tesis dan Disertasi.Jakarta: Pustaka Nusantara Indonesia, 2015

Subekti. Pokok-Pokok Hukum Perdata Jakarta: PT Intermasa, 1995

Suhar. Kaidah-Kaidah Ushuliyah \& Fiqhiyah. Jakarta: Referensi Gaung Persada Press Group, 2014

Syah, Abdullah, Integrasi Antara Hukum Islam dan Hukum Adat Dalam Kewarisan Suku Melayu (Bandung : Citapustaka Media Perintis, 2009)

Tim Penyusun. Bidang Studi Syari'ah. Jakarta: Bagian Proyek Peningkatan Mutu Madrasah Aliyah, 1984

Zainuddin Ali, Metode Penelitian Hukum Jakarta: Sinar Grafika, 2009 